\title{
An Overview of the Main Trends in the Creation of Biodegradable Polymer Materials
}

\author{
Irina N. Vikhareva $(\mathbb{D}$, Evgeniya A. Buylova $(\mathbb{D}$, Gulnara U. Yarmuhametova $(\mathbb{D}$, \\ Guliya K. Aminova, and Aliya K. Mazitova \\ Applied and Natural Sciences Department, Ufa State Petroleum Technological University, Mendeleeva St. 195, 450080 Ufa, Russia \\ Correspondence should be addressed to Irina N. Vikhareva; irina.vikhareva2009@yandex.ru
}

Received 23 May 2021; Accepted 14 July 2021; Published 26 July 2021

Academic Editor: Dario Pasini

Copyright (C) 2021 Irina N. Vikhareva et al. This is an open access article distributed under the Creative Commons Attribution License, which permits unrestricted use, distribution, and reproduction in any medium, provided the original work is properly cited.

\begin{abstract}
Plastic is one of the most demanded materials on the planet, and the increasing consumption of which contributes to the accumulation of significant amounts of waste based on it. For this reason, a new approach to the development of these materials has been formed: the production of polymers with constant operational characteristics during the period of consumption and capable of then being destroyed under the influence of environmental factors and being involved in the metabolic processes of natural biosystems. The paper outlines the prerequisites for the development of the field of creating biodegradable composite materials, as well as the main technical solutions for obtaining such polymeric materials. The main current solutions for reducing and regulating the degradation time of polymer materials are presented. The most promising ways of further development of the field of bioplastics production are described. Common types of polymers based on renewable raw materials, composites with their use, and modified materials from natural and synthetic polymers are considered.
\end{abstract}

\section{Introduction}

The first work in the field of creating biodegradable composite materials is associated with the 1973 oil crisis in the United States: the question arose about the partial replacement of oil with renewable raw materials. In 1976 US Patent No. 3950282, polymers are described with the addition of cellulose oligomers [1]. After the crisis ended, this problem was forgotten for a while. However, later in the 1980s, it drew attention to the growing volumes of disposal of household waste, which are not subject to either recycling or biodegradation. Information about the development of biodegradable PM (polymer materials) has appeared in the literature. In 1980 US Patent No. 4337181, the use of biodegradable films based on starch was proposed [2]. Then, in 1981, an application was filed for the invention of a biodegradable PM based on lactones (US Patent No. 4379138) [3]. However, these were only sporadic attempts to develop biodegradable materials. Active work in this direction began in the 1990s.
The main sources of raw materials for obtaining materials and products from polymers capable of controlled biodegradation in nature are natural compounds: starch, cellulose derivatives, chitin, chitosan, lactic acid, and hydroxyalkanoates. The listed polymers in nature under the influence of microorganisms, water, and soil decompose mainly into carbon dioxide and water. One of the main advantages of natural biodegradable polymers is the possibility of their constant reproduction in nature.

However, traditional polymers are characterized by increased physical, mechanical, and operational properties, and biological stability compared to biopolymers $[4,5]$. Obtaining composites on their basis is an effective and economically profitable modification method, allows to fully use the properties of both types of polymers, and also contributes to the disposal of industrial polymer waste, such as polyethylene, polypropylene, polyvinyl chloride, and polyethylene terephthalate.

One of the methods for producing biodegradable synthetic plastics is the production of polymers, and the 
molecules of which contain fragments that accelerate biodegradation, for example, polyesters and polyesteramides, copolyesters based on aliphatic diols, and organic dicarboxylic acids [6, 7].

Another method for creating biodegradable PM is the development of composites based on natural polymers, for example, starch, cellulose, chitosan, or proteins [7-10]. It is important to choose the right ratio of components, at which the operational properties of the obtained PM approach the properties of the original conventional polymers.

\section{General Information on Biodegradable Polymers}

To date, bioplastics account for only about $1 \%$ of total PM production. Three main groups $[5,11-13]$ are distinguished:

(i) Biobased or partially biodegradable biobased plastics such as biobased polyethylene, polypropylene, or polyethylene terephthalate

(ii) Biobased and biodegradable plastics such as PLA and PHA or PBS

(iii) Plastics derived from fossil resources and biodegradable, e.g., PBAT

The characteristics of the main types of biopolymers are presented in Table 1.

When recycling polymer wastes in soil, microorganisms that can transform various organic compounds play a major role, ensuring self-purification of the environment $[5,14,15]$. For this reason, the destruction of synthetic polymers in nature becomes very problematic, since such compounds do not have their own consumer in the biosphere.

Not all bioplastics are biodegradable and decompose faster than synthetic polymers [16]. The main methods for preparing biodegradable polymers are as follows [17]:

(1) Obtaining from natural polymers using mechanical and chemical processing (biodegradable plastic from destructured starch, from cellulose)

(2) Chemical synthesis of polymers from monomers obtained by biomodification of renewable raw materials (polylactic acid)

(3) Obtaining a biotechnological method from renewable raw materials (fermentation of sugars using microorganisms to obtain thermoplastic aliphatic polyesters, polyhydroxyalkanoates (PHAs), and bacterial cellulose).

(4) Chemical synthesis from petroleum products and other nonrenewable sources of raw materials (traditional plastics with biodegradable additives).

Today, in the world, there are more than 100 types of various biodegradable polymers $[18,19]$. The main resources for obtaining them are shown in Figure 1 [20].

For biodegradable PM, it is very important that all additives are also biodegradable and nontoxic. Thus, the standards for compostable PM require testing not only the polymers themselves, but also all additives in the final product in order to exclude their negative effect on compost [21-23].

Thus, the biodegradability of PM does not depend on the resource base of the material but is determined by the size of the molecule, chemical structure, and the presence and nature of side groups, as well as by the supramolecular micro- and macrostructure. The increase in biodegradation is facilitated by the presence of groups in the polymer chain that are easily hydrolyzed, presence of substituents, an increase in the degree of chain substitution and the length of its sections between functional groups, and increased flexibility of macromolecules [8-10, 24-27].

Biodegradation is a biochemical reaction catalyzed by enzymes and metabolites of microorganisms [27]. In the presence of free oxygen, aerobic biodegradation occurs in the system. Under aerobic conditions, biodegradation products are carbon dioxide, water, hydrocarbon residues, hydrocarbon biomass, and salts. Under anaerobic conditions, i.e., without oxygen, methane is added to the reaction products. When the PM is immersed in the ground, the access of oxygen is limited; therefore, the release of methane is possible.

A necessary condition of the biodegradation process is the presence of a minimum amount of water [28-30]. In this case, the rate of biodegradation is determined mainly by the following factors: temperature, pressure, presence of salts, $\mathrm{pH}$ value, presence of trace elements and nutrients, redox potentials, certain environmental conditions, microorganisms, presence of inhibitors, intensity, and wavelength of light.

The type of soil is also significantly important for biodegradation, namely, the species composition of microorganisms and their number, soil structure, the amount of organic residues, fertility, and other reasons [31]. The largest number of microorganisms lives in the soil at a depth of $50-150 \mathrm{~mm}$ ( $1 \mathrm{~g}$ of soil contains up to 108 units of microorganisms).

There are several classifications of approaches to solving the problem of polymer utilization. In particular, the authors distinguish four main approaches [32]:

(1) Selection of special strains of microorganisms that carry out polymer degradation. For example, bacteria of the genus Pseudomonas sp. were obtained from the soil by selection methods, which produce an enzyme that breaks down polyvinyl alcohol. After hydrolysis of polymer macromolecules based on polyvinyl alcohol, the fragments are completely absorbed by these bacteria. The bacteria Pseudomonas sp. are introduced into activated sludge at water treatment plants for a more complete treatment of wastewater from this polymer.

(2) Synthesis of biodegradable polymers by microbiotechnology methods. In particular, this method was used to obtain polymers that are close in their plastic properties to classical polymers: polyethylene and polypropylene. 
TABle 1: The characteristics of the main types of biopolymers.

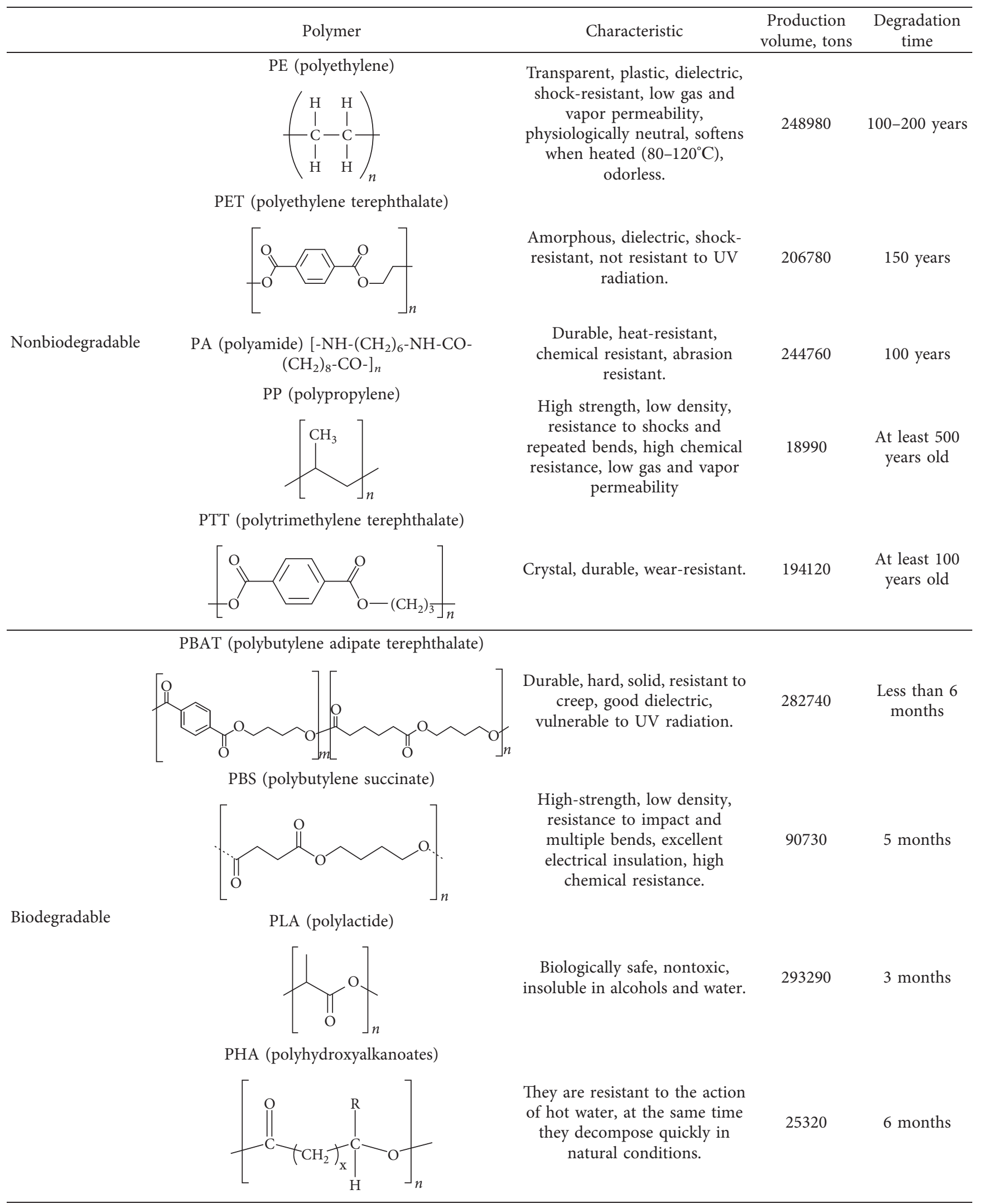






FIgURE 1: Resources for obtaining biodegradable PM.

(3) Synthesis of biodegradable polymeric materials with a chemical structure similar to that of natural polymers. An example is a polyester having a chemical structure similar to cellulose polyoxyacetobutyrate. A polymer analog of lignin, methoxystyrene, was synthesized; complex polyester, which includes lactic and phenyl lactic acids.

(4) Development of materials based on renewable biological resources.

The various technological additives of organic nature (plasticizers, stabilizers, and fillers) included in PM are a source of biogenic elements for microorganisms and contribute to reducing the resistance of PM to biodegradation, while inorganic components (silicates, sulfates, phosphates, and carbonates) do not support microorganism growth [33, 34].

Stability of PM to biological degradation is also influenced by macrostructural characteristics: uniformity of component distribution in mass, pore size, features of product surface treatment, and technological parameters of PM manufacturing $[33,34]$.

\section{Methods for Assessing the Biodegradability of PM}

Biodegradability assessment methods are divided according to the following classification features [35]:

(i) Test conditions: laboratory and full-scale

(ii) Duration: long-term and express methods (iii) Regulation level: standard and nonstandard

(iv) The determined biodegradability parameter: studying the kinetics of changes in the characteristics of biodegradable polymeric materials (BPMs) (biofouling, weight, strain-strength indicators, the degree of degradation of the macro-, micro-, and molecular structure of samples, the molecular weight distribution of the polymer binder, etc.) or studying the kinetics of changes in the composition and properties of the biological system in which biodegradation occurs (respiratory activity, acidity, chemical and microbiologic composition of the soil or other biological medium, etc.)

The most commonly used methods for testing the biodegradability of composite materials are shown in Table 2 .

The main criterion for the classification of methods for assessing biodegradability is the conditions of the experiment: laboratory or natural.

The advantages of laboratory methods for testing the biodegradability of PM are as follows: the possibility of changing in a given direction the biochemical composition of the environment, temperature, humidity and other experimental conditions; the ability to determine the capacity of individual strains of microorganisms to utilize PM and, accordingly, select the most active microbial associations. These testing methods include fungal resistance test, gas emission assessment (the method for determining the respiratory activity of the soil), imitation of natural soil 
TABLE 2: Methods for assessing the biological degradation of polymer composite materials.

\begin{tabular}{|c|c|c|c|c|c|}
\hline Method & The essence of the method & $\begin{array}{l}\text { Experiment } \\
\text { time }\end{array}$ & $\begin{array}{c}\text { Experimental } \\
\text { conditions }\end{array}$ & Applied cultures & Standard \\
\hline Mycological test & $\begin{array}{l}\text { Determination of material } \\
\text { resistance to the effects of } \\
\text { mold cultures }\end{array}$ & 28 days & $\begin{array}{l}\text { Temperature } 29 \pm 2^{\circ} \mathrm{C} \\
\text { Humidity over } 90 \% \\
\text { Illumination } 200-300 \mathrm{~lx}\end{array}$ & $\begin{array}{l}\text { Mold and } \\
\text { microscopic fungi }\end{array}$ & $\begin{array}{c}\text { ISO } 846 \text { ASTM } \\
\text { G 21-2015 State } \\
\text { standard } \\
9.049-91 \\
\end{array}$ \\
\hline Bacterial test & $\begin{array}{l}\text { Determination of material } \\
\text { resistance to bacteria cultures }\end{array}$ & - & $\begin{array}{c}\text { Temperature } 20^{\circ} \mathrm{C} \\
\text { Humidity over } 58 \% \\
\text { Illumination } 200-300 \mathrm{~lx} \\
\end{array}$ & lls & ISO 846 \\
\hline $\begin{array}{l}\text { Biodegradability of } \\
\text { insoluble substances }\end{array}$ & $\begin{array}{c}\text { Determination of the amount } \\
\text { of } \mathrm{O}_{2} \text { absorbed during } \\
\text { aerobic degradation }\end{array}$ & 4 months & $\begin{array}{l}\text { Anaerobic conditions, } \\
\text { buffer mineral medium, } \\
\text { solid medium }\end{array}$ & $\begin{array}{c}\text { Inoculant from } \\
\text { activated sludge or } \\
\text { waste water }\end{array}$ & $\begin{array}{l}\text { ISO } 10708 \\
\text { OECD } 301 \mathrm{D}\end{array}$ \\
\hline Free space test at $25 / 50^{\circ} \mathrm{C}$ & $\begin{array}{l}\text { Determination of the amount } \\
\text { of } \mathrm{CO}_{2} \text { released during } \\
\text { incubation of the material }\end{array}$ & 48 days & $\begin{array}{l}\text { Temperature } 25-50^{\circ} \mathrm{C} \text {, } \\
\text { Humidity } 60-70 \%, \\
\text { Illumination } 200-300 \mathrm{~lx}, \\
\text { Anaerobic environment }\end{array}$ & $\begin{array}{l}\text { Mixed population } \\
\text { of microorganisms }\end{array}$ & $\begin{array}{c}\text { ASTM } \\
\text { D5988-96 } \\
\text { OECD } 301 \text { A }\end{array}$ \\
\hline Shturm method & $\begin{array}{l}\text { Determination of the released } \\
\mathrm{CO}_{2} \text { in the process of } \\
\text { material degradation }\end{array}$ & 6 months & $\begin{array}{c}\text { Temperature } 20-25^{\circ} \mathrm{C}, \\
\text { Illumination } 200-300 \mathrm{~lx} \text {, } \\
\text { Water solution, Aerobic } \\
\text { environment }\end{array}$ & $\begin{array}{l}\text { Fungal or bacterial } \\
\text { flora }\end{array}$ & $\begin{array}{l}\text { ISO 9439, ISO } \\
\text { 14852, DIN EN } \\
\text { 29439, ASTM } \\
\text { D 5209 }\end{array}$ \\
\hline $\begin{array}{l}\text { Determination of released } \\
\mathrm{CO}_{2} \text { (aerobic test in } \\
\text { compost) }\end{array}$ & $\begin{array}{c}\text { Determination of released } \\
\mathrm{CO}_{2} \text { in the process of } \\
\text { material degradation in } \\
\text { compost }\end{array}$ & 6 months & $\begin{array}{l}\text { Aerobic environment, } \\
\text { Compost based on the } \\
\text { organic fraction of } \\
\text { municipal solid waste }\end{array}$ & Aerobic bacteria & $\begin{array}{l}\text { ISO } 14855, \\
\text { ASTM D } 6400\end{array}$ \\
\hline $\begin{array}{l}\text { Determination of the } \\
\text { degree of decomposition } \\
\text { in compost }\end{array}$ & $\begin{array}{c}\text { Determination of the degree } \\
\text { of decomposition of material } \\
\text { in a model industrial } \\
\text { compost }\end{array}$ & 90 days & $\begin{array}{c}\text { Temperature } 58 \pm 2^{\circ} \mathrm{C} \text {, } \\
\text { Air exchange, Darkness } \\
\text { or stray light, Industrial } \\
\text { compost }\end{array}$ & $\begin{array}{l}\text { Inoculant, } \\
\text { thermophilic } \\
\text { bacteria }\end{array}$ & $\begin{array}{c}\text { ISO } 16929, \text { ISO } \\
20200, \text { BS EN } \\
14045\end{array}$ \\
\hline Soil test & $\begin{array}{l}\text { Determination of absorbed } \\
\mathrm{O}_{2} \text { or released } \mathrm{CO}_{2} \text { in the } \\
\text { process of material } \\
\text { degradation in natural soil of } \\
\text { the upper layer of fields }\end{array}$ & 6 months & $\begin{array}{c}\text { Temperature } 28 \pm 2^{\circ} \mathrm{C} \\
\text { Soil moisture } 30 \pm 5 \% \\
\text { pH }-7.5, \text { Soil biological } \\
\text { activity coefficient } \\
0.65-1.5\end{array}$ & $\begin{array}{l}\text { Soil } \\
\text { microorganisms }\end{array}$ & $\begin{array}{l}\text { ISO } 17556, \text { DIN } \\
53739, \text { State } \\
\text { standard } \\
9.060-75\end{array}$ \\
\hline
\end{tabular}

conditions, incubation with microorganisms, composting, separation method during centrifugation, bioindicator and spectral methods (IR spectroscopy, fluorescence method, and indicator thin layer chromatography), water absorption and leaching, biodegradation (the soil test on reconstituted soil), biodegradation by molds, biodegradation of fillers, and biodegradation of film samples [21, 36-39].

Laboratory methods do not always allow simulating a complex of endogenous and exogenous factors that determine the process of PM biodegradation in the natural environment [21]. For this, full-scale tests of BPM are carried out.

Natural methods make it possible to obtain the most reliable data on the kinetics and mechanism of PM biodegradation, since the test conditions are as close as possible to the real conditions for the disposal of solid polymer waste. The difficulty in interpreting the results of field tests is that in the natural environment there is a continuous change in its chemical and microbiological composition, temperature, humidity, $\mathrm{pH}$, aeration conditions, etc. Main natural methods: microbiological resistance test, soil burial test, moisture absorption, and soil test in real conditions.

There is a wide range of laboratory and field methods for studying the biodegradability of BPM. The most productive, obviously, should be considered an integrated approach to the study of biodegradation of polymeric materials. To determine reliable kinetic parameters and elucidate the mechanism of this process, a comparative analysis of the results of a number of independent physicochemical, biochemical, and microbiological experiments was carried out both in the laboratory and in natural conditions.

\section{Biodegradable Polymers}

\subsection{Natural Biodegradable Polymers}

4.1.1. High-Molecular Weight Carbohydrates. Polysaccharides are the most common group of biopolymers in nature, due to which vital processes occur in the animal world, in plants and microorganisms [40]. Polysaccharide resources are constantly renewable. Development of biodegradable composites with properties similar to traditional plastics is important for using these biopolymers for practical purposes as a replacement for synthetic large-tonnage polymers [41, 42].

Polysaccharides are high-molecular weight compounds built from the elementary units of monosaccharides, combined with each other by glycosidic (acetal) bonds. Their molecular weight ranges from several thousand to millions. 
4.1.2. Starch. Starch, a mixture of amylose and amylopectin polysaccharides, the monomer of which is alpha-glucose, accumulates in the cells of seeds, bulbs, and tubers, as well as in leaves and stems. The source of starch on an industrial scale is potatoes, corn, wheat, rice, sweet potatoes, sago palm, and sorghum. It is produced from crushed raw materials after washing with water, separating waste, and precipitating in a centrifuge from starch washing liquid in the form of starch milk with a moisture content of up to $36 \%$; after further purification, it is dehydrated and dried to a moisture content of $20 \%$.

The use of starch as a base for biocomposites is explained by a number of reasons [43]:

(i) Renewability and availability

(ii) The presence of useful properties (hydrophilicity, resistance to organic solvents, biodegradability, and high absorbing capacity in relation to some reagents)

(iii) The possibility of modifying its structure

Due to its structure, starch can crystallize, and its granules exhibit hydrophilic properties and are also capable of forming strong associates through hydrogen bonds between $\mathrm{OH}$ groups on the surface of the granules. The destruction of the crystal structure by the action of mechanical factors, pressure, heat, and the addition of plasticizers imparts thermoplasticity to the polymer [44].

To create bioplastics, chemically modified starch is also used, in which hydroxyl groups are replaced by various ester groups. Such a modification of starch leads to a change in its basic properties: hydrophilic, rheological, and physicochemical.

In order to prevent excessive swelling of granules during gelatinization, another method of starch modification is carried out, cross-linking due to hydroxyl groups [42].

Such modified starch is used for the manufacture of various products. Starch copolymers and starch-based composites are used as thermoplastic materials [45].

By adding silica, thermoplastic starch is obtained in the form of nanocomposites with a water content of less than $10 \%[46]$.

Destructured starch is used in composites with synthetic polymers (polyethylene and polyvinyl alcohol) [47]. The composite consists of three phases: starch, synthetic polymer, and the "penetration" zone, which provides a strong interaction between the two polymers. The starch content together with the plasticizer in such plastics can be about $40 \%$. Composites have excellent physical and mechanical properties for packaging purposes, but their biodegradability depends on the synthetic component. Composites with aliphatic polyesters (polylactide and its copolymers) are mainly used in production [47].

A wide range of chemical, mechanical, and rheological properties of composites with starch content is possible due to the formation of two types of supramolecular starch structures (droplet-like and layered) with the introduction of complexing agents (deoxy succinates, epoxies, and layered organosilicates) [48]. The resulting materials are characterized by different periods of biodegradation.

Thus, the possibility of starch modification makes it possible to create original solutions from both technological and environmental points of view [49].

Starch is also used as a component of biodegradable composites. When starch, pectin, and plasticizers (glycerin or polyoxyethylene glycol) are mixed, water-soluble films degraded by bacteria are obtained [49]. At the same time, with an increase in starch content, the fragility of the film increases. When mixed with amylose and a small amount of weak acids, sheets are obtained by extrusion, from which they are blow molded for packaging. Compositions containing a mixture of high amylose and normal starch and plasticized with glycerin, urea, and polyethylene glycol are processed on a twin-screw extruder. Next, a film is obtained from the granules, producing compostable films for agriculture and packaging.

The use of raw starch mixed with polyvinyl alcohol and talc reduces the cost of biodegradable household materials [49]. Granular starch mixed with $10-30 \%$ aqueous solution of polyvinyl alcohol allows you to get stronger, flexible, and water-resistant foam sheets and disposable dishes that decompose in seven days. To accelerate biodegradation and improve technological and operational properties, polyester polymers, for example, polyester of hydroxycarboxylic acids, are introduced into the composition.

The use of starch in a mixture with polyethylene glycol and polyoxybutyrate makes it possible to obtain water-resistant composites [50].

Films based on degraded starch, impregnated with a copolymer of ethylene with vinyl alcohol and aliphatic polyesters, have high strength, retain properties at $50^{\circ} \mathrm{C}$ for months, and are used for biodegradable diapers and sanitary pads and in agriculture for mulching and in food packaging [51].

Biotec $\mathrm{GmbH}$ manufactures starch-based compostable plastics for various applications, capable of decomposing in compost at $0^{\circ} \mathrm{C}$ within 2 months:

(i) Injection-molded bioplastic in the form of granules for disposable products

(ii) Foams for food products

(iii) Granules for the production of compostable films [52]

The Czech company Fatra has developed Eco-fol packaging film based on starch with polyolefin, which decomposes in 3-4 months [53].

4.1.3. Cellulose. Cellulose is a natural polymeric polysaccharide, and the macromolecule of which is built from repeating $\beta$-glucose residues. The polymerization coefficient for cellulose depends on the origin: for wood pulp, 3000; for cotton, 12000; and for linen, 36000 [54].

The main source of cellulose is wood. Cellulose fibers are flexible, strong, resiliently elastic, capable of reversibly deforming without destruction even under high mechanical stress, insoluble in water and organic solvents, and 
nonthermoplastic, withstand heating up to $150^{\circ} \mathrm{C}$ without destruction [55].

Thermoplastic and soluble cellulose derivatives are obtained by chemical modification.

The most important in practical terms and best studied are cellulose ethers and esters obtained by interaction with $\mathrm{OH}$ groups ( 3 alcohol hydroxyls) in each monosaccharide unit $[56,57]$. These polymers are used in the production of artificial fibers, plastics, films, paints and varnishes, smokeless powder, explosives, and solid rocket fuels.

Other modifications of cellulose are also obtained: alkaline (under the action of sodium hydroxide solution), carboxymethyl cellulose (ether with glycolic acid), methyl cellulose of three modifications (methyl cellulose ether), mono-, di-, and triacetyl cellulose (cellulose triacetate), and nitrocellulose of three modifications (cellulose nitrates) [55].

Acetate films are used in agriculture to cover greenhouses due to their ability to transmit ultraviolet rays. Acetyl cellulose plastics are used for the manufacture of steering wheels for aircraft and automobiles [55].

Nitrocellulose is the basis of the first man-made plastic (celluloid). Its main disadvantage is easy flammability and release of toxic nitrogen oxides during combustion [55].

Viscose fiber and cellophane are also obtained from cellulose by chemical modification. First, when the alcohol $\mathrm{OH}$ group interacts with carbon disulfide in an aqueous solution of alkali, a soluble salt (xanthate) is obtained, and then, during the spinning process through spinnerets into a precipitation bath with an acid solution, the xanthate is hydrolyzed and cellulose is regenerated in the form of thin threads called viscose fiber [55].

When plasticizing such a fiber with glycerin, cellophane is obtained. Nonstick cellophane with low vapor and moisture permeability is obtained by covering with a thin film of polyethylene, cellulose acetate, polyvinyl chloride, and other polymers (duplication), used as a packaging material for food products, consumer goods, and technical products, and in medicine as implanted material. Viscose is used for the production of artificial leather (kersey), viscose nonfibrous products, and spinning of viscose fiber [58].

Etrol plastic is obtained on the basis of acetates, acetopropionates, acetobutyrates, cellulose nitrates, and ethyl cellulose. It also includes plasticizers, stabilizers, dyes, alloying additives, mineral fillers, and substances that increase biostability [57]. Etrols are processed by methods typical of thermoplastics. The resulting products are characterized by high mechanical properties and good appearance and are easily processed by mechanical methods. Steering wheels, armrest, instrument panels, buttons, and handles for various vehicles are released from etrols, as well as phone parts, natural gas pipes, transparent sheets for viewing windows, toys, and eyeglass frames.

Lignin, a polymer contained in the membrane of a plant cell of cellulose, a nonhydrolyzable part of wood, is a mixture of aromatic polymers with a similar structure [59]. Lignin binds cellulose molecules together, imparting structural rigidity. Wood contains $18-30 \%$ lignin, depending on the species and on the age (lignification) of the plant. Lignin is nontoxic, has universal characteristics, and is used in many industries.

Lignin is obtained as a waste in the production of cellulose (sulfate lignin and lignosulfonic acids) and hydrolysis of plant materials (hydrolysis lignin). Nevertheless, lignin is a valuable chemical raw material for various industries.

In the compound of biodegradable compositions, lignin is used as a filler that loosens the structure and, as a result, promotes water absorption and an increase in the number of microorganisms [60].

4.1.4. Chitin. Chitin is a natural nitrogen-containing unbranched polysaccharide with a linear conformation of macromolecules, fixed by a system of intra- and intermolecular hydrogen bonds [61]. It is a rigid translucent material. The molecular weight of chitin reaches 260,000 .

In nature, chitin is found in the shells of sea crabs, shrimps, krill, lobsters, and crayfish; in the outer skeleton of zooplankton, corals, and jellyfish; and in insects in their wings. The cell walls of yeast and fungi also contain this natural polymer [61].

In all organisms, chitin is not contained in pure form, but in a complex with other polysaccharides, and is often associated with proteins. The long length, limited flexibility of macromolecules, and the regularity of the structure of the polymer chain of chitin contribute to the formation of a highly ordered structure characteristic of the crystalline state of polymers. Crystalline regions in the structure of chitin are $60-85 \%$, depending on the origin and method of isolation. There are three crystallographic modifications, which differ in the arrangement of molecular chains in the unit cell of the crystallite [62].

The most common modification is $\alpha$-chitin. It is characterized by a close packing of macromolecules and is provided by antiparallel arrangement of chains in the unit cell. $\beta$-Chitin is an unstable crystal hydrate with a parallel arrangement of chains. The $\gamma$-chitin cell has two parallel chains and one antiparallel to them. All modifications exist in one organism and perform different biological functions.

Chitin is insoluble in water, dilute solutions of acids, alkalis and organic solvents. When dissolved in concentrated solutions of hydrochloric, sulfuric, and formic acids, chitin is depolymerized fragmentarily, and when heated in these solutions, it hydrolyzes with destruction [62]. For this reason, the extraction of chitin is carried out using chemical treatment with acids, alkalis, and complex ones or by biotechnology methods by the action of enzyme preparations and proteolytic bacteria. The first method is based on one- or two-stage purification of chitin from protein, it is deproteination, and from the mineral part, it is demineralization.

Due to a number of unique properties, namely, chemical and radiation resistance, bactericidal action, high sorption capacity, and the ability to interact with other polymers due to the presence of polar $\mathrm{OH}$ groups and amino groups, chitin is widely used in various fields of industry. The world production of chitin and its derivatives is about 3000 tons per year. 
The wide possibilities of chemical modification of chitin for obtaining materials of various structures and properties contribute to its use for solving environmental problems by using it in biodegradable polymers [63].

4.1.5. Chitosan. Chitosan is a linear polydispersed polymer aminopolysaccharide, the simplest derivative of chitin, obtained by deacetylation of chitin [64]. The deacetylation reaction is accompanied by the rupture of the polymer glycosidic bonds. The molecular weight of chitosan ranges from 3800 to 20,000 .

The presence of two hydroxyl groups (at C-3, secondary; at C-6, primary) contributes to the production of chitosan ethers and esters. Amino groups in the structure have a $\mathrm{pKa}$ value of $\sim 6.5$ and are capable of protonation in acidic media and to obtain $\mathrm{N}$-derivatives of various types. Unlike chitin, chitosan is soluble in dilute solutions of organic and inorganic acids (except for sulfuric acid) and has wider application possibilities [65].

Chitosan is a universal sorbent for substances of organic and inorganic nature. A large number of hydrogen bonds in the polymer structure provide a high sorption capacity in relation to organic water-soluble compounds and bacterial toxins but leads to poor solubility in water. However, chitosan swells well and firmly retains the solvent, dissolved and suspended substances in its structure. Moreover, in dissolved form, chitosan has a greater sorption capacity [66].

Due to hydrophobic interactions and molecular sieve effect, chitosan is able to bind saturated hydrocarbons, fats, and fat-soluble compounds.

During processing, the deacetylation reaction mainly occurs in the amorphous regions, and the crystalline regions will contain residual acetyl groups [67]. The distribution of these groups after processing noticeably affects the deformation and strength properties of the fibers.

The structural heterogeneity of chitosan is associated with the prehistory of the initial chitin, its supramolecular structure, and the parameters of the chitin deacetylation regime. With the enzymatic hydrolysis of chitosan, lowmolecular weight oligosaccharides are obtained that have biodegradability and biocompatibility; that is, they penetrate well into biological media (blood, lymph, tissue, and articular fluid) and are not toxic. This contributed to the development of "therapeutic nanotechnology" using chitosan nanofibers. The nanofibers obtained from a chitosan solution by the method of electrospinning (Nanospider technology) are distinguished by an ultradeveloped surface and porosity and have an effective wound-healing effect and bactericidal activity for creating dressings [68].

The characteristics of a polymer material for biomedical three-dimensional frameworks for tissue engineering and three-dimensional in vitro tissue models based on microstructured chitosan/poly $(\gamma$-glutamic acid) in the form of polyelectrolyte complex hydrogels were studied using computer wet pressing [69].

As a result, the resulting hydrogel swells and has thermal and mechanical properties, which makes it possible to obtain more rigid microstructured hydrogels for a better cell reaction in vitro compared to freeze-dried hydrogels.

4.1.6. Natural Rubber. Rubber is a natural polymer with a very long chain; it is contained in the milky sap of the Hevea brasiliensis tree and is excreted in the form of an elastic amorphous mass, and is used in tires, hoses, and conveyor belts [20]. The main area of application of rubber is the production of tires and rubber products, electrical insulating materials, and rubber products for household use, and in the manufacture of rubber adhesives. The volume of production of natural rubber in 2017 amounted to about 12.4 million tons.

A type of rubber is the less elastic gutta-percha, which is extracted from the latex of the euonymus tree. The difference between these polymers lies in the different spatial structure of their macromolecules. In the rubber macromolecule, the chain sections at each multiple bond are in the cis position, and in the gutta-percha macromolecule, and in the trans position.

Currently, gutta-percha is used for the production of chewing gums and golf balls and in dentistry (material for fillings) [20].

Rubber is isolated from latex by coagulation with formic, oxalic, or acetic acid. The resulting loose clot (coagulum) is washed with water and rolled on rollers to obtain sheets, which are dried and smoked in chambers. Smoking ensures that the rubber is resistant to oxidation and microorganisms. Raw rubber contains impurities of protein compounds and oxygen-containing resins, which negatively affect its technical properties. The purified rubber of composition $\left(\mathrm{C}_{5} \mathrm{H}_{8}\right)_{\mathrm{x}}$ is easily soluble in benzene, carbon disulfide, and chloroform. Dry distillation of the rubber also yields dipentene $\mathrm{C}_{10} \mathrm{H}_{16}$ and isoprene $\mathrm{C}_{5} \mathrm{H}_{8}$. The subsequent processing of the rubber with sulfur or sulfur chloride $\mathrm{S}_{2} \mathrm{Cl}_{2}$ results in an extremely elastic mass-vulcanized rubber. Latex mixtures contain many ingredients: curing agents, vulcanization accelerators and activators, antioxidants, powder fillers, surfactants, antistabilizing additives that reduce the stability of the colloidal system, thickeners, plasticizers, defoamers, or foam stabilizers [20].

The duration of mixing the composition is 30-60 minutes, and sometimes the mixture "matures" for 6-24hours at $20-60^{\circ} \mathrm{C}$ and slow stirring. The process is accompanied by a change in colloidal-chemical characteristics: $\mathrm{pH}$ decreases, viscosity increases, and homogeneity increases; technological properties are improved. Latex is used to obtain gloves, meteorological, radiosonde, and balloon pilots, medical products, rubber threads, sponge rubber, light rubber and sports shoes, and latex adhesives for various purposes, in the manufacture of sheet plywood and other wood products, in the production of textile materials and carpets, and for production of abrasive materials in combination with melamine-formaldehyde oligomers.

However, the production of stereoregular synthetic rubbers contributed to a reduction in the use of natural rubber in a number of industries [20]. 
4.1.7. Polyhydroxyalkanoates. Polyhydroxyalkanoates, polymers of natural origin, derivatives of polyoxybutyric acid, are synthesized by some types of microorganisms, are found in the cytoplasm of microbial cells in the form of granules, and usually account for $40 \%$ of their dry weight [68]. Polyhydroxyalkanoates are rapidly degraded by soil and water microorganisms. The most promising is poly-3oxybutyrate or polyhydroxybutyrate (PHB), discovered by microbiologists in 1925. Bacterial PHB is characterized by good elastic-strength properties, optical activity, thermoplasticity, and piezoelectric properties. The polymer is insoluble in water, ether, lower alcohols, and acetone [70].

Products from such polymers are obtained from a melt or from its solutions in organic solvents, pyridine, dioxane, higher alcohols, camphor, and chloroform, used in pure form and as a component of mixtures and copolymers based on it [71]. PHB can be processed on standard industrial equipment for forming filaments, films, and other products. In terms of technological characteristics, it is practically superior to traditional thermoplastics. Products from PHB do not require special disposal and do not pollute the environment [72]. The production of PHB is waste-free and characterized by low energy consumption.

PHB has found application in medicine as absorbable suture threads, dressings and tampons, plates, and rods in orthopedics; in the form of a film material is used for packaging and storage of food products, for disposable packaging materials; and in the form of capsules for prolonged action of drugs, stimulating plant growth, and mineral fertilizers [73].

The compatibility of this biopolymer with some industrial polymers, for example, with polyethylene and cellulose ethers, contributed to the creation of new multicomponent PM, which significantly reduces the cost of products in comparison with pure PHB. The piezoelectric properties and optical activity inherent in PHB significantly expand the range of applications for these bioplastics $[73,74]$. Thus, the listed advantages of biodegradable polymers of this class undoubtedly stimulate their increased demand and contribute to further research.

4.1.8. Protein. Proteins are complex organic compounds with molecular weights from 14,000 to 45,000 and more and are found in animal and plant organisms [75]. Most of the protein is found in meat, fish, cheese, eggs, soy, nuts, and peas. More than 5 million proteins are found in the human body, and all of them are not similar to each other. Despite the complexity of the structure and the huge variety, proteins are built from only 20 amino acids with a different order of alternation.

When functioning, a protein molecule undergoes dynamic transformations associated with the ways of packing a protein thread into a coil (globule).

The amino acids of proteins contain polar functional groups that have an affinity for water; therefore, proteins dissolve well in water with the formation of unstable colloidal solutions due to the large size of the molecules [76]. Amino acids of proteins are linked by hydrogen bonds through $\mathrm{CO}$-groups of one amino acid residue and $\mathrm{NH}$ groups of another residue.

Under the action of dehydrating compounds (alcohol, acetone, and salts), proteins precipitate. Proteins of some tissues are able to retain up to $99 \%$ of water in their cells, forming a kind of framework.

Proteins are not widely used for the production of biodegradable composites. However, the use of block copolymers for medical purposes is known [77].

4.1.9. Polyglutamic Acid. PGA is a rare anionic polymer compound consisting of an extremely viscous homopolyamide of $\mathrm{D}$ - and L-glutamic acid units and an extracellular polymer that is completely biodegradable and nontoxic to humans [78-81]. PGA is synthesized by several microorganisms; however, for commercial proposals, $B a$ cillus species (B. licheniformis and B. subtilis) are usually used to produce PGA.

PGA was first discovered in 1973 by Ivanovic and his colleagues in the form of a capsule in Bacillus anthracis (a sporulation Gram-positive bacterium and the causative agent of anthrax), which was released into the medium during autoclaving, aging, or autolysis of cells [82].

Gamma PGA has a wide number of potential uses ranging from food and medicine to water treatment.

In [83], a new approach to the controlled functionalization of bacterial $\gamma$-PGA is reported, implemented using several control levels. Thus, it is possible to reduce the molecular weight of the native biopolymer using a mechanochemical approach, maintaining the integrity of the polymer and the initial dispersion of the molecular weight. A synthetic modification was carried out in a homogeneous phase in organic solvents with control of the degree of substitution of reactive functional groups. The degrees of polymerization of the developed macromolecular derivatives published in the study are promising for use in biomaterials and polymers for the healthcare sector.

\subsection{Synthetic Biodegradable Polymers}

4.2.1. Polyolefins (Polyethylene and Polypropylene). In 1950, a photodegradable carbo-chain polymer-copolymer of ethylene and carbon dioxide was obtained by DuPont for the first time, but the rate of photobiodegradation of the resulting polymer was low [84, 85]. In 1972 in the USA, the first composite film BPM based on polyethylene with a starch additive was produced and the serial production of compostable sack containers was carried out [86]. Biodegradation of the developed container proceeded at temperatures above $70^{\circ} \mathrm{C}$.

Coloroll Ltd. in 1975 mastered the industrial production of biodegradable films based on LDPE (low-density polyethylene) and bioplastic starch for the manufacture of food packaging, bottles, and bags for fertilizers and other products for agriculture [86].

The use of starch in the serial production of biodegradable PM based on polyethylene has been mastered by several companies: packaging material under the Mater-Bi 
brand from Novamont S.p.A. (Italy); Polyclean TM concentrate for the production of biodegradable films from Archer Daniels Midland (USA); Ecostar Plus concentrate from St. Lawrence Starch (USA). In addition to starch, the composition includes additives that act as a catalyst for the biodegradation of starch [87-89].

Such composites have taken a firm place in the packaging materials market [88]. Since starch is poorly compatible with nonpolar polyethylene, improving the compatibility of these polymers is carried out mainly in two ways:

(a) The use of a third more polar polymer. Most often for these purposes, copolymers of ethylene with vinyl acetate (EVA) or saponification products of acetate groups in these copolymers.

(b) Modification of the structure of starches (for example, esters of starch and higher fatty acids). These ester groups containing long alkyl radicals act as internal plasticizers. However, the rate of biodegradation of these composites is lower.

The most famous product with the addition of starch is the Mater-Bi material from Novamont S.p.A (Italy). The composite is produced on the basis of a mixture of starch and is also recycled, degrades in soil in 60 days both under aerobic and anaerobic conditions without the release of harmful products [87].

For biodegradable packaging in order to reduce the cost of PM, composites are being developed based on polyethylene and polypropylene wastes with the addition of wastes from flour and cereals, starch, sugar, and confectionery enterprises [63, 89]. The compatibility of thermoplastic extrusion components depends on the nature of the polymers, their ratio, chemical composition, particle size, and raw material moisture. The best compatibility is obtained if the filler particles are 100-500 microns in size. High humidity negatively affects the physical and mechanical properties of the plastic compound.

It is known to use chitin and chitosan as fillers; the content of polysaccharides varies from 20 to $50 \mathrm{wt}$. \%. Their unique qualities provide chemical and radiation resistance, high sorption capacity, and bactericidal action. The presence of hydroxyl and amino groups makes it possible to modify their structures for wide application. Films made from a mixture of LDPE with chitosan, due to the peculiarities of its morphology, are poorly processed by microorganisms $[90,91]$.

Since chitosan is soluble in aqueous media, water-soluble polymers are used for compositions with its use, for example, polyvinyl alcohol, polyethylene glycol, and polyvinylpyrrolidone [92-94].

Photodegradable copolymers of ethylene with carbon monoxide have been developed. Photoinitiators of decomposition are vinyl ketone monomers in the amount of $2-5 \%$.

For the same purpose, cellulose pulp, alkyl ketones, or fragments containing carbonyl groups are used. The resulting films for agriculture based on polyethylene, polypropylene, and polyethylene terephthalate are stored for 8-12 weeks, then photo- and biodegradable.
Iron and nickel dithiocarbamate and their peroxides are also used as photosensitive additives for polyolefins [95].

4.2.2. Polyvinyl Chloride. The main direction in the development of biodegradable materials based on polyvinyl chloride is the use of additives that accelerate the biodegradation process. The latter are often represented by natural high-molecular compounds constituting various food products: starch, rye, corn and wheat flour, barley grains processing wastes, millet, buckwheat, wood processing products (wood flour), cellulose and its derivatives, and lignin $[95,96]$. The formulation also includes a nutrient component that is yeast or blue-green algae.

The introduction of fillers weakens the polymer chain of PVC molecules and promotes interaction with $\mathrm{OH}$ groups in the cellulose structure. When it enters the soil, the formed monomeric fragments are a nutrient medium for microorganisms. Biodegradation of such plastics ranges from 6 to 36 months [97]. PVC molecules also undergo biodegradation, although to a less significant extent and for a longer time. Initially, long chains of polyvinyl chloride break down into shorter fragments, which are further destroyed by soil microorganisms and are further destroyed.

Plasticizers present in PVC compositions also increase biodegradation. The more resistant to the action of microorganisms are PVC materials plasticized with phthalates of higher alcohols, low biostability in compositions containing dioctyl sebacate $[98,99]$. Ester plasticizers degrade under the influence of micromycetes, which break down the ester bond, and also due to the oxidation of the ester by enzymes. The authors of the submitted article are developing a class of nontoxic biodegradable plasticizers based on adipic acid and oxyalkylated aliphatic and aromatic alcohols. The use of such alcohols helps to increase the degree of decomposition of the material, since ether bonds are easily hydrolyzed. We are also investigating the possibility of using the developed adipates in PVC compositions, studying the effect of the obtained plasticizers on the biodegradation of plastics, as well as the ecotoxicity of their decay products [100-103].

4.2.3. Polystyrene. Starch is mainly used as a biodegradable additive for the creation of biodegradable composites based on polystyrene $[104,105]$. For this purpose, the starch was pretreated at various temperatures, selecting the optimal temperature mode for molding, and an impact-resistant bioplastic was obtained, processed by extrusion and injection molding.

To improve the compatibility of polymer components, copolymers of polystyrene and maleic anhydride were proposed [106]. The resulting compositions are well formed, have satisfactory mechanical characteristics, and are also capable of degradation under the action of fungal spores. To create biodegradable plastics based on PS, it is necessary to select components and manufacturing parameters in order to combine a high level of performance of polystyrene (strength, low gas and moisture permeability, environmental safety, and good formability) with biodegradability. 
It is known to obtain photodegradable polymers based on PS by synthesizing styrene copolymers with carbon monoxide [107]. The introduction of vinyl ketone monomers in an amount of $2-5 \%$ as a copolymer to styrene makes it possible to obtain photodegradable polymers. Photodegradation of these bioplastics occurs when exposed to ultraviolet radiation in the range of $290-320 \mathrm{~nm}$.

Of interest are the developed functionalized polymers and copolymers of styrene as polymer binders in biodegradable plastics. The range of such bioplastics is small, and their cost is 2-3 times higher than the cost of large-capacity, nonbiodegradable polymers [108].

4.2.4. Polyesters and Polyesteramides. Polyesters are highmolecular weight compounds containing ester groups in the main chain.

Polyethylene terephthalate (PET) and polybutylene terephthalate (PBT) are characterized by high biostability [109-112]. The resistance of plastics obtained on their basis depends on the introduced low-molecular additives (plasticizers, fillers, dyes, stabilizers, and modifiers), which can be an easily accessible substrate for microorganisms and, accordingly, the cause of a decrease in the fungal resistance of the material. However, if the polymer envelops the filler well, the mushroom resistance of the resulting composition is high.

Basically, the resistance of plastic compounds to fungi is determined by its chemical structure. Readily available sites for most mycodestructors are fragments of the carbon chain of a polymer molecule with double bonds, as well as susceptible to hydrolysis. A decrease in the distance between ester bonds and the absence of branching in a macromolecule also facilitate the biodegradation of PM $[7,17,24,113,114]$.

Oxyacids may be used as modifying components to provide polyester-based PM.

Also, an expected method of increasing the biodegradability of PET is compounding it with a biodegradable component, for example, with starch. However, during the composting process, only starch is rapidly decomposed, and PET mostly does not biodegrade [109-112].

4.2.5. Polylactides. Polylactide is a thermoplastic polymer. The starting material for the preparation of polylactide is lactic acid (2-hydroxypropionic acid), which exists in two optically active configurations: $\mathrm{L}$ and $\mathrm{D}$. Varying the ratio of $\mathrm{L}$ - and D-isomers makes it possible to obtain an amorphous or crystalline high-molecular weight polymer [115-117].

The industrial synthesis of high-molecular weight polylactide $(100,000)$ is currently carried out by polymerization of lactide. Initially, an oligomer is obtained, then it is cyclized into lactide, and deep purification is carried out and polymerized with opening of the lactide ring [118-120].

Mitsui Chemicals has introduced a solution method for producing polylactide, in which lactic acid is azeotropically polycondensed in the presence of a catalyst with stirring in a high-boiling aprotic solvent [42].
Today, polylactide is one of the cheapest biodegradable plastics. Despite the fact that the raw materials for this polymer are much more expensive than conventional packaging materials, such as polyethylene and polystyrene, the costs at the end of the service life may be lower. Biodegradation of polylactide depends on temperature, the presence of low-molecular weight impurities, and traces of the catalyst [118-121].

Despite the widespread industrialization of the polymerization method for producing polylactide, the development of a less energy-intensive process continues. By solid-phase polycondensation in the presence of catalysts based on lead and tin, the possibility of obtaining condensation polylactide with a molecular weight of 72,000 was shown. For this purpose, tin octanoate was most widely used. However, recently, organotin compounds are gradually being replaced by other catalysts, since tin is a heavy metal and, when ingested, can generate pathological changes at the cellular level [122]. In this regard, the use of catalysts based on aluminum, titanium, magnesium, and calcium is being studied. To increase the stereospecificity of the process, compounds of zirconium, hafnium, gold, and platinum are used as catalysts [122, 123].

The preparation of polylactide with a molecular weight of 102,000 and an extremely high melting point $\left(210-218^{\circ} \mathrm{C}\right)$ due to the formation of a special supramolecular structure, a stereo complex of L- and D-polylactide, has been described [122, 123].

Another effective method for reducing the negative effect of oligomeric oxyacid impurities present in lactide is the combination of polymerization and polycondensation processes for the synthesis of polylactide. Specially selected conditions for increasing the induction period of polymerization by lowering the temperature lead to a decrease in the polymerization rate in an open system, and the condensation of impurities and the removal of the resulting water reduce the concentration of chain transmitters [124].

A technology for the production of polylactide by the extruder method has been developed, which makes it possible to carry out continuous polymer synthesis and obtain finished products directly at the exit from the extruder. The advantages of the method in comparison with the batch technology are the homogeneity of mixing and heat transfer of the entire reaction mass, the absence of low molecular weight fractions, a narrow molecular weight distribution, and the exclusion of the polymer granulation stage. All these lead to a decrease in the cost of polylactide and ensure the production of wares with high-performance characteristics [124].

Polylactide is convenient for use in packages with a suitable shelf life. When disposed of, it is hydrolyzed into natural and safe products. In recent years, polylactide has been used primarily for biomedical purposes, disposable food products, and textiles [122-125].

Despite the advantages of polylactide (compatibility with the human body, nonallergenicity, resistance to hydrolysis even in boiling water, and absence of toxic metabolites), the rate of its biodegradation (half-life is 168 days) is high 
enough, which significantly limits the possibilities of its use. The preparation of biodegradable copolymers of lactic acid with a controlled biodegradation rate is of interest.

The most promising comonomer is glycolide, which is obtained from glycolic or monochloroacetic acid. Polyglycolide is a polyester in which intermolecular interactions are strongly expressed due to the close arrangement of ester groups, which leads to thermal and hydrolytic instability [126].

Polyglycolide has acceptable resorption periods in a living organism (6-12 months); however, due to hydrolytic instability, it rather quickly (up to 20 days) loses about $60 \%$ of its strength, which imposes certain restrictions on its use as a surgical material.

/The synthesis of copolymers of various compositions based on lactic and glycolic acids makes it possible to successfully combine the properties of polylactide and polyglycolide and control the rate of biodegradation. Polymers can be obtained with different molecular weights and structures of macromolecules [127, 128].

By varying the amount and time of introduction of one of the monomers, it is possible to purposefully change the structure of the material and its properties, for example, the period of complete degradation of the polymer. Thus, with an increase in the content of lactic acid fragments in the copolymer macromolecule, hydrophobicity increases, but crystallinity decreases.

\section{Conclusions}

Analysis of literature data showed that the main technical solutions in the field of creating biodegradable polymer materials are in the development of alternative plastics that do not accumulate in nature, but are characterized by environmental friendliness, as well as the possibility of modifying the required specified service life and subsequently accelerated degradation in natural conditions. These materials include polylactides, polyesters, and others. The most promising among them are polyhydroxyalkanoates, since they are distinguished by wide possibilities for modeling the structure and properties of the resulting bioplastics, which are close to those of traditional synthetic polymer materials based on petrochemical raw materials. However, at present, their serial production has not been organized, which is primarily due to the availability of raw materials and its high cost, and it also remains not fully justified to reduce the risk of the negative impact of the decay products of bioplastics on nature and the animal world.

For this reason, in our opinion, a promising innovative direction is the use of composite materials based on largetonnage traditional polymers, such as PE, PP, and PVC, obtained using petrochemical raw materials by introducing environmentally friendly safe additives that provide them with accelerated biodegradation in natural conditions. At the present level, the development of this area is also characterized by the most environmentally friendly, energy and resource saving technologies that provide them with undeniable advantages.

\section{Data Availability}

The data used to support the findings of this study are included within the article.

\section{Conflicts of Interest}

The authors declare no conflicts of interest.

\section{References}

[1] Gilbert, D. Richard, Stannett, Vivian, T. Kim, and L. Soojaa, "Polyanhydroglucose biodegradable polymers and process of preparation," United States Patent 3,950,282, 1976.

[2] Otey, H. Felix, Westhoff, and P. Richard, "Biodegradable starch-based blown films," United States Patent No. 4337181, 1982.

[3] C. G. Pitt and E. Schindler \& Anton, "Biodegradable polymers of lactones," United States Patent No. 4379138, 1983.

[4] A. V. Petrov, M. S. Doriomedov, and S. Yu. Skripachev, "Technologies for recycling polymer composite materials (review)," Works Of All-Russian Institute of Aviation Materials, vol. 8, pp. 62-73, 2015.

[5] N. R. Prokopchuk, A. F. Manulenko, and A. V. Evsey, "Some features of recycling and regulation of properties of secondary polyvinyl chloride," Proceedings of BSTU. Chemistry, Technology of Organic Substances and Biotechnology, vol. 4, pp. 112-114, 2010.

[6] E. G. Mădălina, "Methods of recycling, properties and applications of recycled thermoplastic polymers," Recycling, vol. 2, no. 24, pp. 1-11, 2017.

[7] A. A. Tager, Physico-Chemistry of Polymers, Publishing House "Chemistry", Moscow, Russia, 1968.

[8] S. P. Rybkina, V. A. Pakharenk, T. S. Shostak, and V. V. Pakharenko, "The main directions in the field of creating biodegradable thermoplastics," Plastic Masses, vol. 10, pp. 47-54, 2008.

[9] G. M. Vlasova, A. V. Makarevich, and L. S. Pinchuk, "Biodegradable films based on thermoplastics," Reports of the National Academy of Sciences of Belarus, vol. 44, no. 6, pp. 100-103, 2000.

[10] O. Legonkova, A. Melitskova, and A. Peshekhonova, "Biodegradation is the future," Container and Packaging, vol. 2, pp. 62-63, 2003.

[11] D. Carrington, "Researchers race to make bioplastics from straw and food waste," 2018, http://www.polyestertime.com/ researchers-race-make-bioplastics-straw-food-waste/.

[12] News, "Biodegradable plastic made from plants, not oil, is emerging," 2008, http://abcnews.go.com.

[13] M. M. Reddy, S. Vivekanandhan, M. Misra, S. K. Bhatia, and A. Mohanty, "Biobased plastics and bionanocomposites: current status and future opportunities," Progress in Polymer Science, vol. 38, pp. 1653-1689, 2013.

[14] R. B. Palyga, "Potential possibilities of polymer processing," Solid Household Waste, vol. 1, no. 127, pp. 26-29, 2017.

[15] V. N. Davydova, V. A. Lukasik, and Yu. V. Solovyova, Recycling of Thermoplastics and Reactoplasts, p. 56, VolgSTU, Volgograd, Russia, 2014.

[16] "Bioplastics (PLA), world centric," worldcentric.org, 2018.

[17] E. L. Pekhtasheva, Biodamages and Protection of Non-food Products, p. 224, Mastership, Moscow, Russia, 2002.

[18] E. L. Parmukhina, "Russian market of biodegradable packaging," Ecological Bulletin of Russia; Research company RESEARCH. TECHART, vol. 2, pp. 32-33, 2011. 
[19] M. T. Zumstein, R. Narayan, H.-P. E. Kohler, K. McNeill, and M. Sander, "Dos and do nots when assessing the biodegradation of plastics," Environmental Science \& Technology, vol. 53, no. 17, pp. 9967-9969, 2019.

[20] I. B. Bogatova, Polymers and Polymer Materials in the Food Industry, p. 93, Cassandra, Tolyatti, Russia, 2010.

[21] O. A. Ermolovich, A. V. Makarevich, E. P. Goncharova, and G. M. Vlasova, "Methods for assessing the Biodegradability of polymer materials," Biotechnology, vol. 4, pp. 47-54, 2005.

[22] S. V. Vlasov and A. A. Olkhov, "Biodegradable polymer materials," Polymer Materials: Products, Equipment, Technologies, vol. 7, pp. 23-26, 2006.

[23] A. Popov, "Biodegradable polymer materials," Packaging and Packaging, vol. 3, pp. 43-47, 2007.

[24] D. A. Rodionov, I. V. Suvorina, P. V. Makeev, and Yu. V. Knyazev, "Current state in the field of biodegradable polymers and packaging," Young Scientist, vol. 1, no. 105, pp. 265-267, 2016.

[25] O. Legonkova, O. Sdobnikova, and A. Bokarev, "Biodegradable materials in packaging technology," Container and Packaging, vol. 6, pp. 78-80, 2003.

[26] M. L. Sherieva, G. B. Shustov, and R. A. Shetov, "Biodegradable compositions based on starch," Plastic Masses, vol. 10, pp. 29-31, 2004.

[27] J. Summerscales, "A review of bast fibres and their composites: part 4 organisms and enzyme processes," Composites Part A: Applied Science and Manufacturing, vol. 140, Article ID 106149, 2021.

[28] R. J. Müller, "Biodegradability of polymers: regulations and methods for testing," in Biopolymers Online, pp. 365-388, Wiley-VCH, Weinheim, Germany, 2005.

[29] M. Flieger, M. Kantorová, A. Prell, T. Řezanka, and J. Votruba, "Biodegradable plastics from renewable sources," Folia Microbiologica, vol. 48, no. 1, pp. 27-44, 2003.

[30] I. Kyrikou and D. Briassoulis, "Biodegradation of agricultural plastic films: a critical review," Journal of Polymers and the Environment, vol. 15, no. 2, pp. 125-150, 2007.

[31] M. I. Shtilman, "Biodegradation of polymers," Journal of Siberian Federal University. Biology, vol. 8, no. 2, pp. 113130, 2015.

[32] K. S. Miller and J. M. Krochta, "Oxygen and aroma barrier properties of edible films: a review," Trends in Food Science \& Technology, vol. 8, no. 7, pp. 228-237, 1997.

[33] A. A. Klesov, Enzymatic Catalysis, Publishing house of Moscow state University, Moscow, Russia, 1980.

[34] B. N. Stepanenko, Chemistry and Biochemistry of Carbohydrates, Higher school, Moscow, Russia, 1978.

[35] A. I. Suvorova and I. S. Tyukova, "Biodegradable systems: thermodynamics, rheological properties and biocorrosion," High-molecular Compounds, vol. 50, no. 7, pp. 1162-1171, 2008.

[36] State standard 9.049-91, "Unified system of corrosion and ageing protection," Polymer Materials and Their Components. Methods of Laboratory Tests for Mould Resistance, p. 14, Publishing house of standards, Moscow, Russia, 1994.

[37] E. S. Velik, L. V. Rudakova, Yu. V. Kulikova, M. V. Burmistrova, and H. N. Slyusar, "Evaluation of the efficiency of biodegradation of polymer composite materials," Bulletin of Nizhnevartovsk State University, vol. 4, p. 11, 2017.

[38] State standard 4650-2014 (ISO 62:2008), Plastics. Methods for the Determination of Water Absorption, p. 17, Standardinform, Moscow, Russia, 2014.
[39] State standard 9.060-75, "Unified system of corrosion and ageing protection," Fabrics. Method of Laboratory Tests for Microbiological Destruction Stability, p. 14, Publishing House of Standards, Moscow, Russia, 1994.

[40] A. Varki, R. Cummings, J. Esko et al., Essentials of Glycobiology, p. 823, Cold Spring Harbor Laboratory Press, NewYork, USA, 3rd edition, 2017.

[41] S. Rogovina, K. Aleksanyan, L. Vladimirov, E. Prut, N. Ivanushkina, and A. Berlin, "Development of novel biodegradable polysaccharide-based composites and investigation of their structure and properties," Journal of Polymers and the Environment, vol. 26, no. 4, pp. 1727-1736, 2018.

[42] L. Yu, K. Dean, and L. Li, "Polymer blends and composites from renewable resources," Progress in Polymer Science, vol. 31, no. 6, pp. 576-602, 2006.

[43] A. S. Klinkov, Recycling of Polymer Containers and Packaging: A Textbook, TSTU, Tambov, Russia, 2008.

[44] R. D. Maximov, Y. Lilichenko, Y. Zitsans, and R. Merii Meri, "Properties of a biodegradable nanocomposite based on starch and unmodified clay," Plastic Masses, vol. 12, pp. 36-41, 2008.

[45] S. V. Kraus, "Physical and chemical properties of polymer compositions using starch," Storage and Processing of Agricultural Raw Materials, vol. 1, pp. 8-11, 2011.

[46] A. Jiménez, M. J. Fabra, P. Talens, and A. Chiralt, "Edible and biodegradable starch films: a review," Food and Bioprocess Technology, vol. 5, no. 6, pp. 2058-2076, 2012.

[47] O. A. Legonkova, "Packaging materials from biodegradable materials based on polylactide and starch," Food Industry, vol. 6, pp. 12-13, 2009.

[48] S. P. Rybkina, "Biodegradable packaging materials based on polysaccharides (starch)," Plastic Masses, vol. 2, pp. 61-64, 2012.

[49] A. Shafqat, A. Tahir, A. Mahmood, A. B. Tabinda, A. Yasar, and A. Pugazhendhi, "A review on environmental significance carbon foot prints of starch based bio-plastic: a substitute of conventional plastics," Biocatalysis and Agricultural Biotechnology, vol. 27, Article ID 101540, 2020.

[50] O. A. Ermolovich, "Influence of compatibilizer additives on technological and operational characteristics of biodegradable materials based on starch-filled polyethylene," Journal of Applied Chemistry, vol. 79, no. 9, pp. 1542-1547, 2006.

[51] N. S. Vinidiktova et al., "Environmentally friendly oriented films based on polypropylene," Materials. Technologies. Tools, vol. 13, no. 4, pp. 14-19, 2008.

[52] October 2020, https://bbi-biotech.com/.

[53] October 2020, https://www.fatrafloor.cz/ru/.

[54] C. Krumm, J. Pfaendtner, and P. J. Dauenhauer, "Millisecond pulsed films unify the mechanisms of cellulose fragmentation," Chemistry of Materials, vol. 28, no. 9, pp. 3108-3114, 2016.

[55] N. I. Nikitin, Chemistry of Wood and Cellulose, The Science, Moscow, Russia, 1962.

[56] A. P. Belokurova, V. A. Burmistrov, A. E. Chalykh, and O. I. Koifman, "Diffusion and dissolution of water vapor in plasticized cellulose acetates," Plastic Masses, vol. 8, pp. 24-26, 2007.

[57] M. R. Garaeva, E. M. Gotlib, N. N. Nikitina, and A.V. Kostochko, "The influence of the plasticizer on the crystalline structure of cellulose acetates," Plastic Masses, vol. 3, pp. 51-52, 2007. 
[58] Z. A. Rogovin and L. S. Galbreich, Chemical Transformations and Modification of Cellulose, reprint and additional, Chemistry, Moscow, Russia, 2nd edition, 1979.

[59] P. T. Martone, J. M. Estevez, F. Lu et al., "Discovery of lignin in seaweed reveals convergent evolution of cell-wall architecture," Current Biology, vol. 19, no. 2, pp. 169-175, 2009.

[60] Yu.N. Sazanov, "Lignin-polymer composites, news of higher educational institutions," Lesnoy Zhurnal, vol. 5, pp. 153172, 2014.

[61] O. A. Leontieva and L. A. Sukhareva, Thousand and One Polymers from Biostable to Biodegradable, Radiosoft, Moscow, Russia, 2007.

[62] V. P. Varlamov, A. V. Ilina, B. T. Shagdarova, A. P. Lunkov, and I. S. Mysyakina, "Chitin. Chitosan and its derivatives: fundamental and applied aspects," Advances in Biological Chemistry, vol. 60, pp. 317-368, 2020.

[63] J. L. Shamshina, A. Kelly, T. Oldham, and R. D. Rogers, "Agricultural uses of chitin polymers," Environmental Chemistry Letters, vol. 18, no. 1, pp. 53-60, 2020.

[64] I. Younes and M. Rinaudo, "Chitin and chitosan preparation from marine sources. Structure, properties and applications," Marine Drugs, vol. 13, no. 3, pp. 1133-1174, 2015.

[65] M. Barikani, E. Oliaei, H. Seddiqi, and H. Honarkar, "Preparation and application of chitin and its derivatives: a review," Iranian Polymer Journal, vol. 23, no. 4, pp. 307-326, 2014.

[66] Y. I. Cho, H. K. No, and S. P. Meyers, "Physicochemical characteristics and functional properties of various commercial chitin and chitosan products," Journal of Agricultural and Food Chemistry, vol. 46, no. 9, pp. 3839-3843, 1998.

[67] E. J. Vandamme, S. De Baets, and Alexander Steinbüchel, "Biopolymers," in Polysaccharides II: Polysaccharides from Eukaryotes, vol. 6, pp. 275-287, Wiley-VCH, Weinheim, Germany, 2004.

[68] J. L. Leuba, P. Stossel, R. Muzzarelli, C. Jeuniaux, and G. W. Gooday, Chitin in Nature and Technology in Chitosan and Other Polyamines: Antifungal Activity and Interaction with Biological Membranes, Springer, Boston, MA, USA, pp. 215-222, 1986.

[69] D. Puppi, C. Migone, A. Morelli et al., "Microstructured chitosan/poly( $\gamma$-glutamic acid) polyelectrolyte complex hydrogels by computer-aided wet-spinning for biomedical three-dimensional scaffolds," Journal of Bioactive and Compatible Polymers, vol. 31, no. 5, pp. 531-549, 2016.

[70] E. M. Antipov, A. V. Rebrov, Y. P. Nekrasov, S. A. Gordeev, and A. E. Antipov, "Highly oriented fibers of biodegradable polyhydroxyalkanoates," Ecology and Industry of Russia, vol. 5, pp. 30-36, 2010.

[71] T. I. Andreeva, G. A. Bonartseva, N. I. Ermilina, N. A. Zakovryashina, V. I. Kirilovich, and T. N. Prudskova, "Isolation and purification of biodegradable polyhydroxybutyrate for medical devices," Ecology and Industry of Russia, vol. 5, pp. 72-77, 2010.

[72] R. Hatti-Kaul, L. J. Nilsson, B. Zhang, N. Rehnberg, and S. Lundmark, "Designing biobased recyclable polymers for plastics," Trends in Biotechnology, vol. 38, no. 1, pp. 50-67, 2020.

[73] M. Koller, "Switching from petro-plastics to microbial polyhydroxyalkanoates (PHA): the biotechnological escape route of choice out of the plastic predicament?" The EuroBiotech Journal, vol. 3, no. 1, pp. 32-44, 2019.

[74] A. Ya, "Danilevsky, Biologo-chemical messages about protein substances (materials for their chemical Constitution and biogenesis)," Physiological Collection, vol. 1, p. 289, 1988.
[75] R. H. Pain, Mechanisms of Protein Folding, p. 480, Oxford University Press, New York, NY, USA, 2nd edition, 2000.

[76] O. S. Rabotyagova, P. Cebe, and D. L. Kaplan, "Protein-based block copolymers," Biomacromolecules, vol. 12, no. 2, pp. 269-289, 2011.

[77] K. S. Stepanenko, "Marketing research of the market of biodegradable packaging," EVR, vol. 2, pp. 25-31, 2011.

[78] F. B. Oppermann-Sanio and A. Steinbüchel, "Occurrence, functions and biosynthesis of polyamides in microorganisms and biotechnological production," Naturwissenschaften, vol. 89, no. 1, pp. 11-22, 2002.

[79] M. Kunioka and A. Goto, "Biosynthesis of poly ( $\gamma$-glutamic acid) from l-glutamic acid, citric acid, and ammonium sulfate in Bacillus subtilis IFO3335," Applied Microbiology and Biotechnology, vol. 40, no. 6, pp. 867-872, 1994.

[80] H. K. O. Young and R. A. Gross, "Effects of glucose and glycerol on $\gamma$-poly (glutamic acid) formation by Bacillus licheniformis ATCC 9945a," Biotechnol. Bioeng.vol. 57, pp. 430-437, 1997.

[81] S. H. Yoon, J. Hwan Do, S. Yup Lee, and H. Nam Chang, "Production of poly- $\gamma$-glutamic acid by fed-batch culture of Bacillus licheniformis," Biotechnology Letters, vol. 22, no. 7, pp. 585-588, 2000.

[82] I.-L. Shih and Y.-T. Van, "The production of poly-( $\gamma$-glutamic acid) from microorganisms and its various applications," Bioresource Technology, vol. 79, no. 3, pp. 207-225, 2001.

[83] V. Cedrati, A. Pacini, A. Nitti et al., "“Clickable” bacterial poly( $\gamma$-glutamic acid)," Polymer Chemistry, vol. 11, no. 35, pp. 5582-5589, 2020.

[84] https://www.novamont.com/eng/mater-bi, 2020.

[85] https://www.adm.com/, 2020.

[86] https://www.novamont.com/eng/mater-bi, 2020.

[87] https://www.adm.com/, 2020.

[88] John Wiley \& Sons, Encyclopedia of Polymer Sceince and Technology, John Wiley \& Sons Inc, Hoboken, NJ, USA, 2005.

[89] G.-Q. Chen and M. K. Patel, "Plastics derived from biological sources: present and future: a technical and environmental review," Chemical Reviews, vol. 112, no. 4, pp. 2082-2099, 2012.

[90] S. Z. Rogovina, K. V. Aleksanyan, and E. V. Prut, "Biodegradable mixtures of chitin and chitosan with synthetic polymers," Encyclopedia of Chemical Engineers, vol. 6, pp. 32-38, 2011.

[91] P. Nikitenko, "Chitosan-polymer of the future," Science and Innovation, vol. 9, pp. 14-17, 2013.

[92] Yu. K. Lukanina, N. N. Kolesnikova, A. V. Khvatov, A. V. Koroleva, T. V. Monakhova, and A. A. Popov, "Thermo-and photo-oxidation of biodegradable compositions based on polyethylene and natural fillers," Plastic Masses, vol. 5, pp. 40-41, 2007.

[93] S. B. Mishra, A. K. Mishra, N. K. Kaushik, and M. A. Khan, "Study of performance properties of lignin-based polyblends with polyvinyl chloride," Journal of Materials Processing Technology, vol. 183, no. 2-3, pp. 273-276, 2007.

[94] R. O. Olekhnovich, V. E. Sitnikova, S. V. Chereneva, K. V. Volkova, and E. V. Belukhichev, "Study of the kinetics of thermal degradation of polymer composites based on polyvinylchloride film and biopolymer filler," in Proceeding so the International Multidisciplinary Scientific GeoConference, SGEM, vol. 18, Albena, Bulgaria, July 2018.

[95] L. Piergiovanni and S. Limbo, "Plastic packaging materials," In: Food Packaging Materials, Springer, Cham, Switzerland, 2016. 
[96] B. I. Lirova, E. A. Lyutikova, A. N. Degtyareva, V. A. Larionov, S. I. Degtyarev, and B. A. Berkuta, "Influence of the nature of plasticizers on the properties of film material based on VVC," Applied Chemistry, vol. 77, no. 10, pp. 1707-1713, 2007.

[97] B. I. Lirova, E. A. Lyutikova, A. P. Safronov et al., "Study of the migration process from plasticized PVC-based compositions," Applied Chemistry, vol. 79, no. 6, pp. 1018-1027, 2006.

[98] I. N. Vikhareva and E. Builova, "Synthesis and properties of adipic acid esters," Bashkir Chemical Journal, vol. 26, no. 2, pp. 33-36, 2019.

[99] A. K. Mazitova, I. N. Vikhareva, G. K. Aminova, J. N. Savicheva, N. B. Gareeva, and I. R. Shaikhullin, "The influence of nano-additives in the synthesis of eco-friendly polyester plasticizers," Nanotechnologies in Construction A Scientific Internet-Journal, vol. 12, no. 1, pp. 21-26, 2020.

[100] A. K. Mazitova, I. N. Vikhareva, A. R. Maskova, N. B. Gareeva, and I. R. Shaikhullin, "Study of the effect of additives on biodegradation of PVC materials," Nanotechnologies in Construction A Scientific Internet-Journal, vol. 12, no. 2, pp. 94-99, 2020.

[101] A. K. Mazitova, I. N. Vikhareva, G. K. Aminova, and J. N. Savicheva, "Application of zinc oxide to obtain and modify properties of adipate plasticizer of polyvinyl chloride," Polymers, vol. 12, no. 8, p. 1728, 2020.

[102] M. Berruezo, L. Ludueña, E. Rodriguez, and V. Alvarez, "Preparation and characterization of polystyrene/starch blends for packaging applications," Journal of Plastic Film \& Sheeting, vol. 30, no. 2, pp. 141-161, 2013.

[103] H. A. Pushpadass, R. W. Weber, J. J. Dumais, and M. A. Hanna, "Biodegradation characteristics of starchpolystyrene loose-fill foams in a composting mediums," Bioresource Technology, vol. 101, no. 19, pp. 7258-7264, 2010.

[104] A. Leszek, G. Utracki, Z.-H. Shi, D. Rodrigue, and R. Gonzalez-Núñez, "Compounding polymer blends," Polymer Blends Handbook, pp. 919-1028, 2014.

[105] B. D. Favis, "Polymer alloys and blends: recent advances," The Canadian Journal of Chemical Engineering, vol. 69, no. 3, pp. 619-625, 1991.

[106] M. Okamoto and T. Inoue, "Reactive processing of polymer blends: analysis of the change in morphological and interfacial parameters with processing," Polymer Engineering and Science, vol. 33, no. 3, pp. 175-182, 1993.

[107] L. A. Utracki, "Polymer blends handbook," Polymer Blends Handbook, Kluwer Academic Publishers, Bordrecht, The Netherlands, pp. 547-576, 2003.

[108] S. B. Brown, Reactive Compatibilization of Polymer Blends in Polymer Blends Handbook, Kluwer Academic Publishers, Bordrecht, The Netherlands, 2003.

[109] R. Wang and W. Wang, "Synergistic effect of dual rubber system in toughening styrene maleic anhydride copolymers," Journal of Applied Polymer Science, vol. 90, no. 8, pp. 2260-2267, 2003.

[110] L.-Y. Yang, D. Bigio, and T. G. Smith, "Melt blending of linear low-density polyethylene and polystyrene in a Haake internal mixer. II. Morphology-processing relationships," Journal of Applied Polymer Science, vol. 58, no. 1, pp. 129141, 1995.

[111] Y. B. Kim and R. W. Lenz, "Polyesters from microorganisms," Biopolyesters, vol. 71, pp. 51-79, 2001.

[112] H. Chua, P. H. F. Yu, and C. K. Ma, "Accumulation of biopolymers in activated sludge biomass," Applied
Biochemistry and Biotechnology, vol. 78, no. 1-3, pp. 389-400, 1999.

[113] S. I. Belousov, O. I. Bogdanova, T. N. Ovchinnikova, D. K. Polyakov, N. G. Sedush, and S. N. Chvalun, "Polylactide is a biodegradable, biocompatible polymer based on vegetable raw materials," Ecology and Industry of Russia, vol. 5, pp. 18-23, 2010.

[114] V. A. Fomin, S. P. Sineokiy, S. A. Zavrazhnov, Yu. A. Rybakov, and G. N. Chervyakova, "Development of a technological process for obtaining biodegradable polymers based on lactic acid," Ecology and Industry of Russia, vol. 5, pp. 9-12, 2010.

[115] S. I. Shkurenko, E. V. Monakhova, A. G. Petrov, V. V. Bakholdina, and V. A. Kudryashov, "Biodegradable polymers based on polylactic acid," Ecology and Industry of Russia, vol. 5, pp. 13-17, 2010.

[116] T. Maharana, B. Mohanty, and Y. S. Negi, "Melt-solid polycondensation of lactic acid and its biodegradability," Progress in Polymer Science, vol. 34, no. 1, pp. 99-124, 2009.

[117] D. Garlotta, "Literature review of poly(lactic acid)," Journal of Polymers and the Environment, vol. 9, no. 2, pp. 63-84, 2001.

[118] A. N. Kamluk and A. O. Likhamanau, "Experimental determination of the rational geometrical parameters of the sprinkler frame arms and deflector on the expansion rate and stability of foam," Proceedings of the National Academy of Sciences of Belarus, Physical-Technical Series, vol. 64, no. 1, pp. 60-68, 2019.

[119] D. Belov, "Biodegradable polymer polylactide," Science and Innovation, vol. 9, pp. 21-23, 2013.

[120] V. A. Fomin, "State and directions of development of works on obtaining biodegradable polymers from lactic acid," Plastic Masses, vol. 3, pp. 56-64, 2012.

[121] G. Nordberg, B. Fowler, and M. Nordberg, Handbook on the Toxicology of Metals, Vol. 2, Elsevier, Amsterdam, The Netherlands, 4th edition, 2015.

[122] A. Seifalian, "Market analysis on biomaterials and biomedical engineering," Insights Biomed, vol. 4, p. 15, 2019.

[123] F.-J. Lai, S.-J. Chung, Y.-L. Chang et al., "Comparison of L-lactide polymerization by using magnesium complexes bearing 2-(arylideneamino)phenolate and 2-((arylimino) methyl)phenolate ligands," European Polymer Journal, vol. 135, Article ID 109864, 2020.

[124] M. Ayyoob, S. Lee, and Y. J. Kim, "Well-defined high molecular weight polyglycolide-b-poly(L-)lactide-b-polyglycolide triblock copolymers: synthesis, characterization and microstructural analysis," Journal of Polymer Research, vol. 27, no. 5, p. 109, 2020.

[125] R. E. Cameron and A. Kamvari-Moghaddam, "Synthetic bioresorbable polymers," in Durability and Reliability of Medical Polymers, pp. 96-118, Woodhead Publishing, Sawston, UK, 2012.

[126] P. Dobrzynski, J. Kasperczyk, H. Janeczek, and M. Bero, "Synthesis of biodegradable glycolide/l-lactide copolymers using iron compounds as initiators," Polymer, vol. 43, no. 9, pp. 2595-2601, 2002.

[127] G. Gorrasi, A. Meduri, P. Rizzarelli et al., "Preparation of poly(glycolide-co-lactide)s through a green process: analysis of structural, thermal, and barrier properties," Reactive and Functional Polymers, vol. 109, pp. 70-78, 2016.

[128] L. I. Ramdhanie, S. R. Aubuchon, E. D. Boland et al., "Thermal and mechanical characterization of electrospun blends of poly(lactic acid) and poly(glycolic acid)," Polymer Journal, vol. 38, no. 11, pp. 1137-1145, 2006. 